Number 1

\title{
PENURUNAN KADAR KOLESTEROL TOTAL DAN TRIGLISERIDA DENGAN TEKNIK BEKAM PADA PENDERITA HIPERKOLESTEROLEMIA
}

\author{
Hendra Budi Sungkawa ${ }^{1}$, Wahdaniah ${ }^{2}$ \\ 1,2 Jurusan Analis Kesehataan Poltekkes Kemenkes Pontianak \\ Email: hendrabudis.budis@gmail.com
}

\begin{abstract}
:
Background :Cupping is one type of natural treatment by suctioning the skin, cutting and removing blood from the skin surface. Cupping works for various diseases, can cure acute, chronic and degenerative diseases, such as high blood pressure and hypercholesterolemia. Cupping therapy has been carried out since thousands of years BC. Cupping consists of dry cupping and wet cupping.

Method : This study used a pre-experimental design method for the One Group Pre test Post test. The examination method for Total cholesterol and Triglyceride levels was carried out using the CHOD - PAP (Cholesterol Oxydase Para Amino Phenazone) method and GPO - PAP (Glycerol-3-Phosphate Oxydase Para Amino Phenazone). Data were analyzed by T-Test.

Result : Total cholesterol levels before wet cupping $231 \mathrm{mg} / \mathrm{dl}$ and after wet cupping therapy $220 \mathrm{mg} /$ $d l(p=0.000)(r=0.803)$ and Triglyceride levels before wet cupping $184 \mathrm{mg} / \mathrm{dl}$ and after wet cupping therapy $159 \mathrm{mg} / \mathrm{dl}(\mathrm{p}=0,000)(r=0.901)$.

Conclusion : There is a relationship between wet cupping therapy with a decrease in Total Cholesterol and Triglycerides in hypercholesterolemic patients in the working area of the Pinyuh River Inpatient Health Center. For the development of science it is recommended that further research be conducted on the effects of wet cupping therapy on clinical chemical parameters such as creatinine, gout, blood glucose levels, and other blood parameters.
\end{abstract}

Keywords: Cupping, Wet Cupping, Cholesterol,Triglyceride

\section{PENDAHULUAN}

$$
\text { Pengobatan modern kini }
$$

semakin berkembang yang ditunjukan semakin modernnya ilmu pengetahuan dan teknologi di bidang kedokteran modern. Sementara itu pengobatan alamiah juga mengalami tren peningkatan saat ini, tidak hanya di Indonesia namun di Negara-negara lain. Salah satu jenis pengobatan alamiah saat ini adalah terapi bekam ${ }^{(1)}$.

$$
\text { Bekam berarti peristiwa }
$$
penghisapan kulit, penyayatan dan mengeluarkan darahnya dari permukaan kulit, yang kemudian ditampung di dalam gelas ${ }^{(1)}$.Terapi bekam basah merupakan prosedur ekskresi bedah minor dengan melakukan perlukaan pada permukaan kulit untuk mengeluarkan cairan yang mengadung toksik ${ }^{(2)}$.Bekam basah berkhasiat untuk berbagai penyakit, terutama penyakit yang terkait dengan terganggunya sistem peredaran darah ${ }^{(1)}$.

Terapi bekam adalah suatu metode pengobatan dengan mengeluarkan zat toksik yang tidak terekresikan oleh tubuh melalui 
permukaan kulit menggunakan tabung atau gelas vakum yang ditelungkupkan pada permukaan kulit agar menimbulkan bendungan lokal ${ }^{(3)}$.

Pengobatan bekam terbukti bermanfaat karena pengobatan bekam dirangsang pada titik saraf tubuh seperti halnya pengobatan akupuntur. Pada pengobatan akupuntur yang dihasilkan hanya perangsangan, sedangkan bekam selain dirangsang juga terjadi pergerakan aliran darah. Unsur besi dalam darah manusia kadarnya berbeda-beda, berupa unsur panas yang dapat menyebabkan terhambatnya aktifitas sel-sel sehingga mengurangi imunitas terhadap virus ${ }^{(4)}$.

$$
\text { Pembekaman biasanya }
$$

dilakukan pada kutis (permukaan kulit), sub kutis (jaringan bawah kulit)dan jaringan ini akan "rusak". Kerusakan disertai keluarnya darah akibat bekam akan ikut serta keluar beberapa zat berbahaya seperti serotonin, histamin, bradikinin dan zat-zat berbahaya lainnya ${ }^{(5)}$.Bekam basah dapat menyembuhkan penyakit seperti darah tinggi, kanker, asam urat, diabetes militus (kencing manis), kolesterol, dan osteoporosis $^{(3)}$.

Kolesterol adalah lemak yang berperan penting dalam tubuh, namun jika terlalu banyak kolesterol dalam aliran darah jurstru berbahaya bagi tubuh $^{(6)}$. Kadar kolesterol yang abnormal menjadi faktor resikoutama Penyakit Jantung Koroner ${ }^{(7)}$.

Trigliserida adalah salah satu bentuk lemak yang diserap oleh usus setelah mengalami hidrolisis, kemudian masuk ke dalam plasma. Meningkatnya trigliserida akan menambah risiko terjadinya penyakit jantung dan stroke. Seseorang dengan kadar trigliserida tinggi juga cenderung mengalami gangguan tekanan darah (hipertensi) ${ }^{(8)}$.

\section{METODE PENELITIAN}

Penelitian ini menggunakan metode praeksperimen dengan rancangan One Group Pre test Post test, untuk melihat hubungan sebab akibat dari kelompok subjek dengan hiperkolestrolemia yang diobservasi kadar Kolesterol Total dan Trigliserida sebelum dan sesudah dilakukan inervensi bekam. Teknik pengambilan sampel menggunakan Purposive Sampling dengan kriteria usia 25-60 tahun dengan kadar kolesterol total > 200mg/dl. Penentuan jumlah sampel dilakukan dengan menggunakan rumus Lameshow sehingga didapatkan jumlah

Meditory | ISSN Online : 2549-1520, ISSN Cetak : 2338 - 1159, Vol. 7, No. 1, Juni 2019 HIm. 1 - 6, http://ejournal.poltekkes-denpasar.ac.id/index.php/M 
sampel sebanyak 32 responden. Pengukuran dan pemeriksaan kadar Kolestrol Total dan Trigleserida dilakukan dengan metode CHOD PAP (Cholesterol Oxydase Para Amino Phenazone) dan GPO - PAP (Glyserol3-Phosphate Oxydase Para Amino Phenazone). Alat yang digunakan pada pemeriksaan kadar kolesterol total yaitu centrifuge dan fotometer $5010_{\mathrm{v} 5+}$ dengan reagen kit kolesterol dan trigliserida merk AIM menggunakan serum kontrol dengan range 120 - 180 $\mathrm{mg} / \mathrm{dl}$ dan sampel serum didapat pada vena dalam fossa cubiti.

Responden berpuasa selama 10 12 jam sebelum pengambilan sampel darah. Pengambian darah vena dilakukan 1 jam sebelum terapi bekam (pre test) dan 3 jam setelah terapi bekam (post test). Serum kontrol dibuat dengan menambahkan $5 \mathrm{ml}$ aquadest steril yang dihomogenkan dengan menghindari terjadinya buih. Larutan kontrol dimasukkan dalam 20 tabung masing-masing berisi $250 \mu \mathrm{l}$ kemudian tabung ditutup dan dimasukkan ke dalam freezer. Setiap harinya 1 tabung diambil dan dibiarkan larut sendiri dalam suhu kamar sebelum digunakan sebagai kontrol. Serum kontrol diukur dengan Photometer 5010v5+ yang dicocokkan dengan nilai range sehingga pemeriksaan sampel dapat dilanjutkan.

Prosedur pemeriksaan kadar kolesterol total dilakukan dengan metode Enzymatik photometric Test : CHOD - PAP, End Point menggunakan Aim Cholesterol 5 Reagen Kit. Campurkan masing-masing $10 \quad \mu 1$ sampel dengan $1000 \mu 1$ reagen kerja kemudian diinkubasi suhu $37^{\circ} \mathrm{C}$ selama 5 menit. Pemeriksaan Trigliserida dilakukan dengan menggunakan metode GPO-PAP End Point menggunakan AIM Trigliserida. Campurkan $10 \mu 1$ sampel dengan $1000 \mu l$ reagen kerja kemudian diinkubasi suhu $37^{\circ} \mathrm{C}$ selama 5 menit. Absorbansi diukur dengan menggunakan Photometer 5010 5 +.

\section{HASIL DAN PEMBAHASAN}

Hasil pemeriksaan menunjukkan kadar Kolesterol Total dan Tigliserida sesudah bekam menurun, rata - rata terjadi penurunan kadar Kolesterol Total sebanyak 11 poin dan penurunan kadar Trigliserida sebanyak 25 poin. 


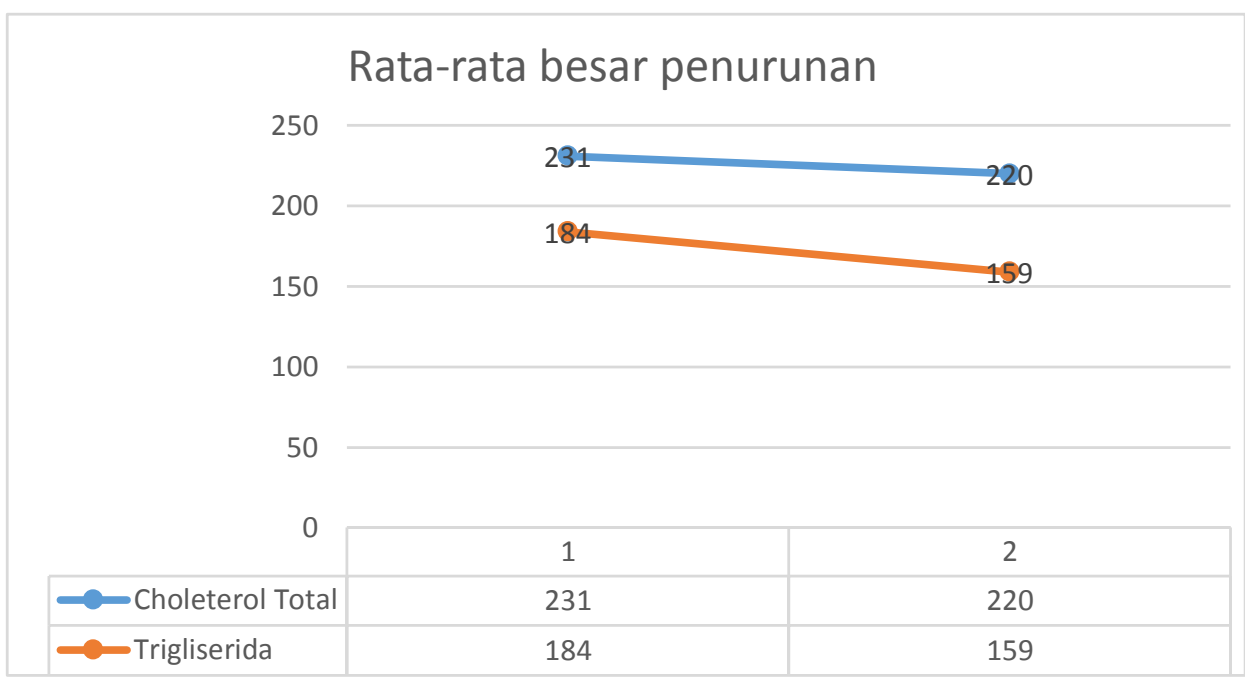

Gambar 1. Penurunan Kolesterol Total dan Trigliserida Sebelum dan Sesudah Bekam $(\mathrm{mg} / \mathrm{dl})$.

Secara umum terjadi penurunan kadar Kolesterol Total dan Trigliserida namun ada beberapa hasil pemeriksaan dimana kadar Kolesterol Total dan Trigiseridanya meningkat, hal ini dapat disebabkan efek hormon yang dipengaruhi oleh hormon lain yang berinteraksi secara bersamaan. Karena hormon tersebar luas melalui darah, selsel sasaran terpapar oleh banyak hormon dalam waktu bersamaan, sehingga timbul interaksi hormon yang kompleks pada sel sasaran. Hormon memilki aktivitas fisiologis yang dapat mengubah reseptor hormon jenis lain, suatu hormon dapat mempengaruhi aktivitas hormon lain pada sel sasaran tertentu.
Respon sel sasaran terhadap hormon berkaitan erat dengan jumlah reseptor sel yang ditempati oleh hormon, tergantung pada jumlah reseptor yang ada di sel sasaran serta konsentrasi hormon dalam plasma. Dengan demikian, respon suatu sel sasaran terhadap konsentrasi plasma tertentu dapat diatur naik atau turun dengan mengubah-ubah jumlah reseptor yang tersedia untuk mengikat hormon. Apabila konsentrasi hormon tertentu meningkat, jumlah reseptor sel sasaran untuk hormon berkurang sebagai akibat langsung dari efek peningkatan hormon terhadap reseptor hormon tersebut. Hal ini disebut down regulation (penekanan), merupakan mekanisme umpan-balik negatif lokal yang 
mencegah sel sasaran bereaksi berlebihan terhadap konsentrasi hormon yang tinggi, sel sasaran mengalami desensitisasi terhadap hormon, yang membantu meringankan efek hipersekresi hormon.

Ada hubungan antara bekam dengan penurunan kadar Kolesterol Total $(\mathrm{p}=0.000)$ dengan kekuatan hubungan kuat $(\mathrm{r}=0.803)$ hubungan tersebut bermakna dengan nilai signifikansi uji $\mathrm{t}=0.000$. Ada hubungan antara bekam dengan penurunan Trigliserida $(\mathrm{p}=0.000)$ dengan kekuatan hubungan sangat kuat $(\mathrm{r}=$ 0.901) hubungan tersebut bermakna dengan nilai signifikansi uji $\mathrm{t}=0.003$.

Teknik yang digunakan untuk mengeluarkan darah bekam adalah dengan penghisapan hingga kulit menggelembung kemudian dilanjutkan dengan teknik sayatan. Luka sayat pada bekam hanya mengenai pembuluh darah kapiler. Penyayatan kulit sampai pada lapisan dermis, yaitu lapisan jaringan ikat yang memiliki banyak serat elastin, kolagen dan sejumlah besar pembuluh darah serta ujung-ujung saraf khusus. Ujung-ujung saraf eferen di dermis mengontrol pembuluh darah, ereksi rambut dan sekresi oleh kelenjar eksokrin kulit.
Respon akibat bekam mengakibatkan aktivitas tirosin kinase intrinsik atau berkaitan dengan protein yang merupakan protein kinase. Protein kinase tunggal menyebabkan fosforilasi residu serin dan treonin di protein target, berperan sangat penting dalam kerja hormon. Reseptor IGF-I (Insulinlike Growth Factor) dan Insulin mengandung aktivitas tirosin kinase intrinsik yang diaktifkan oleh ligan ${ }^{(9)}$.

Penurunan kadar kolesterol dan trigliserida disebabkan karena puasa yang dilakukan oleh pasien mengakibatkan mobilisasi cadangan bahan bakar metabolik. Pada keadaan puasa kadar glukosa di darah menurun, sekresi insulin menurun dan otot rangka serta jaringan lemak menyerap lebih sedikit glukosa. Peningkatan sekresi glukagon oleh sel $\alpha$ pankreas menghambat glikogen sintetase, dan mengaktifkan glikogen fosforilase di hati. Di jaringan adiposa penurunan insulin dan peningkatan glukagon menyebabkan terhambatnya lipogenesis, inaktivasi lipoprotein lipase, dan pengaktifan lipase pekahormon intrasel. Hal ini menyebabkan peningkatan pelepasan gliserol (yaitu substrat untuk glukoneogenesis di hati) dan asam lemak bebas dari jaringan 
adiposa yang digunakan oleh hati, jantung, dan otot rangka sebagai bahan bakar metabolik yang sehingga glukosa dapat dihemat ${ }^{(2)}$.

Keadaan

tersebut

mengakibatkan Asam lemak bebas di dalam plasma meningkat dan akan terus meningkat pada keadaan kelaparan, diikuti kadar plasma badan keton (asetoasetat dan $\beta$-hidroksibutirat) sangat meningkat. Kondisi tersebut menyebabkan hormon-hormon ikut mempercepat pengeluaran asam lemak bebas dari jaringan adiposa dengan meningkatkan lipolisis simpanan TG yaitu, epinefrin, norepinefrin, glukagon, hormon adrenokortikotropik (ACTH), $\alpha$ - dan $\beta$-MSH (Melanocyte Stimulating Hormone), TSH (Thyroid Stimulating Hormone), GH (Growth Hormone), dan vasopresin, hormon-hormon tersebut mengaktifkan lipase peka-hormon ${ }^{(10)}$.

\section{KESIMPULAN}

Ada hubungan terapi bekam basah dengan penurunan Kolesterol Total dan Trigliserida pada penderita hiperkolesterolemia di wilayah kerja Puskesmas Rawat Inap Sungai Pinyuh.
Titik. Solo: Al-Qowam; 2010.

2. Moustafa Abou-El-Naga HSM. Anatomical Sites for Practicing Wet Cupping Therapy (AlHijamah): In Light of Modern Medicine and Prophetic Medicine. Altern Integr Med. 2013;02(08).

3. Kasmui D, Si M, Nabawi KT. Bekam Pengobatan Menurut Sunnah Nabi. 2008;1-52.

4. Fikri Z, Nursalam N, Has EMM. the Reduction of Cholesterol With Cupping Therapy on Cholesterol Reduction in Patients With Hypercholesterolemia. J Ners. 2017;5(2):195-200.

5. Yasin S al - B. Bekam Sunnah Nabi dan Mukjizat Medis. VIII. Jakarta: Al - Qowam; 2007.

6. Nilawati S dr. Care Your Self: Kolesterol. Jakarta: Penebar Plus+; 2008.

7. Soeharto I. Serangan Jantung dan Stroke - Hubungannya dengan Lemak dan Kolesterol. Jakarta: Gramedia Pustaka Utama; 2002.

8. Sutanto. Cekal (cegah dan tangkal) penyakit modern: hipertensi, stroke, jantung, kolesterol, dan diabetes. Yogyakarta: Andi; 2010.

9. Alshowafi FK. Effect of Blood Cupping on Some Biochemical Parameter. Med J Cairo Univ. 2010;78(1):311-5.

10. Hasan I, Alam M, Irshad S. Management of High Blood Cholesterol Levels Through Cupping Therapy in Clinically Healthy Young Men. 2014;1(1):18-23.

\section{DAFTAR PUSTAKA}

1. Umar W. Sembuh Dengan Satu 